\title{
CASTILLA Y EL CASTELLANO; ORIGEN DE UN LUGAR, UN IDIOMA Y UN NOMBRE.
}

Dr. Manuel Antonio Quirós R. *

\section{La romanización y latinización de Hispania}

Cuando la expresión "civis romanus sum" le brotaba, por convicción interna, a un habitante del Imperio Romano, sin importar su procedencia, raza, color, etc., un noble y sano orgullo embargaba su ser; pues era el signo de su romanidad: el sentimiento de sentirse y ser hombre libre, digno poseedor de los mismos deberes, derechos y honores de los que disfrutaba el habitante libre de la Urbs.

La romanidad era un fruto directo de la romanización y latinización: una inmensidad territorial unidad por los vínculos de la cultura $\mathrm{y}$ lengua de Roma, palabra ésta que evocaba, en sus súbitos, respeto, devoción, abnegación y entrega incondicionales.

El proceso histórico de la romanización y el lingüístico de la latinización tuvieron inicio, en Hispania, una vez que los romanos pusieron pie en esta en calidad de aliados contra Aníbal, general cartaginés. Pero desaparecida Cartago, peligrosísima rival de Roma, los romanos se quedarois en ella, no sin pertinaz resistencia de quienes los habían llamado en auxilio. Hispania quedaba, desde el 218 a. Chr. n., ligada y sometida incondicionalmente a Roma.

La conquista hispánica fue llevada a cabo y desde Roma, militar, política, cultural y lingüísticamente, a partir de dos regiones: la del nordeste o Provincia Tarraconense, y la del sur o Bética.

Dado que el idioma castellano es continuación directa de la lengua latina vulgar penetrada en su respectiva área de origen, el norte peninsular, sobre todo en la región de Cantabria como efecto de la romanización y latinización, presentamos ambos hechos:

El primero consiste en la aceptación (impuesta) de la cultura romana, asimilada con la griega, por los aborígenes peninsulares; en efecto, Roma logra impregnar con ella a sus territorios conquistados. Hispania no constituye ninguna excepción a los planes elaborados por los romanos.

* Profesor Gramática histórica y filosofía Románica de la Universidad de Costa Rica.
El segundo es la imposición del latín en los territorios de avanzada romana.

Insistimos: sin ambos procesos no se habría llevado a cabo la castellanización: el origen, desarrollo y penetración del castellano; pues su nacimiento es consecuencia del latín vulgar arraigado en su área de origen.

De las regiones hispánicas susodichas, la más romanizada fue la "Hispania Ulterior", conocida como "Baetica". En las demás, excepto en el Mediterráneo -lugar del primer desembarco romano- la romanización no fue tan profunda.

La romanización y la latinización son fruto del gran interés que siente Roma por Hispania, la cual, a decir de Mommsen, fue el baluarte del romanismo, por ser una de las más antiguas conquistas y la más aculturizada. Sin embargo, tal interés va sobre todo dirigido hacia la explotación, extracción y comercialización principalmente de minerales, que producirán grandes dividendos para las arcas del erario público romano. Esto explica la rapidez con que fueron conquistadas y romanizadas muchas regiones peninsulares. Por consiguiente, Hispania se convirtió en la tierra de colonización por excelencia con el respectivo desvanecimiento de casi toda forma de vida autóctona y peculiar de sus primitivos habitantes: iberos, celtas, turdetanos, galaicos, vacceos, astures, cántabros, capetanos, oretanos, vetones, lusitanos, bastetanos, ilegertes, etc., y quedó asimilada a una manera de vida "romana"; aspecto beneficioso; pues estas tribus constituían una mezcla abigarrada de razas, culturas, religiones, lenguas, costumbres, etc., carentes del principio de la ley y prontas para caer presas de cualquier tribu un poco más ambiciosa y ducha en el manejo de las armas.

Roma les proporcionará a sus súbditos hispanos la unidad; lo que es más, España seguirá siendo invadida por muchísimos pueblos, a lo largo de su historia, de distinta procedencia; sin embargo, se mantendrá fiel al legado de la cultura, heredera de Roma. De hecho, tanto los germanos como los árabes no lograrán suplantar ni sepultar la civilización romana ni el neolatín o romance hispánico. Además, otro aspecto de primerísima importancia: por intermedio de la escuela el pensamiento y las letras griegas se infiltraron en el territorio español. 


\section{Fines de la romanización hispana}

Roma pretendía lo siguiente por medio de la romanización:

1) Ya lo dijimos, la explotación de minerales, de los cuales Hispania era una riquísima cantera;

2) la explotación agrícola -sobre todo del trigo- para satisfacer las necesidades de los productos de que carecía Roma;

3) consecuencia de lo anterior, la incorporación geográfica de casi todo el territorio hispánico y evitar su caída definitiva en poder de Cartago, potente rival de la Urbs;

4) la aculturación de los pueblos sometidos como medio óptimo para un mayor dominio político, y

5) el fomento de la desigualdad social para adquirir esclavos extranjeros.

\section{Manera de efectuar la romanización en Hispa- nia}

Roma empleó, en su política expansiva, diferentesmedios que se pueden enmarcar del siguiente modo:

1) $\mathrm{Al}$ principio - es natural-el más poderoso es la conquista militar, la cual, una vez realizada, se hacía permanecer cierto número de legiones, sobre todo invernales, cuya estadía ocasionaba diferentes tipos de relaciones con los aborígenes;

2) consecuencia directa de lo anterior, es la creación de colonias de veteranos, como Itálica, Forum Iulium, Valentia, Pompaelo, etc.

3) la fundación de centros itálicos y de ciudades, como Hispalis, Hasta Regia, Emporion, etc., para atraer, desde Roma, a hombres poderosos, rivales políticos en potencia;

4) la imposición, manu ferrea, del sistema administrativo-burocrático creado por la Urbe;

5) la influencia de grandes personalidades romanas sobre los habitantes hispanos;

6) el respeto hacia las religiones autóctonas; una especie de liberalismo romano, cuyo ejemplo no fue siempre puesto en práctica por la Roma cristiana;

7) la construcción de toda clase de obras arquitectónicas y de ingeniería, como calles, calzadas, puentes, puertos, faros, acueductos, basílicas, termas, anfiteatros, circos, arcos de triunfo, etc.,

8) las uniones, matrimoniales o no, en cuyo seno familiar, por ser ambas partes de diferente procedencia racial y lingüistica, se fomentaba el bilingüismo;

9) el otorgamiento de la Ciudadania Romana -honroso y aprovechable privilegio- y de derechos y decretos tanto jurídicos como civiles en favor de los súbditos sumisos a los dictados emanados desde Roma; entre otros, sobresalen:

a) el Ius Latinum, otorgado por Vespasiano para toda Hispania, y

b) la Constitutio Antoniana, del 212, por la que Caracalla les concedió la Ciudadania Romana, máxima aspiración de cualquier habitante no romano del Imperio, a todos los súbditos que gozaban de derechos políticos y jurídicos;

10) la acción benéfica de la escuela, manifestada principalmente por una política educativa al estilo de Roma como óptimo medio para que la clase autóctona privilegiada olvidara las costumbres y tradiciones propias y se adaptara más fácilmente el nuevo orden. $\mathrm{La}$ labor de la escuela se manifiesta, en modo esencial, en la implantación del latín clásico; y

11) la introducción y propagación del cristianismo (de procedencia aún oscura, en la Península Ibérica) constituyen la consecuencia culminante del proceso romanizador; en efecto, tal religión proporciona, cristianamente, muchísimos elementos que habían sido previamente asimilados de la cultura romana. el Cristianismo es predicado en latín en el mismo Imperio Romano.

\section{Consecuencias producidas en los aboríge- nes por la romanización}

Transcurrido un lapso determinado, los efectos de la romanización no se hicieron esperar y se manifestaron del siguiente modo:

1) asimilación de nuevas costumbres, como el uso de la toga y demás vestimenta, al estilo romano; 
2) aceptación del nuevo status político, jurídico y administrativo;

3) transformación de la antigua estructura económica, social y cultural; como muestra de la primera está el uso generalizado de la moneda romana;

4) empleo de nuevas técnicas agrícolas e industriales;

5) cambio en las concepciones religiosas, cuyo proceso culminante es el triunfo del cristianismo, con Roma como principal baluarte;

6) la cohesión histórico-cultural que comenzó adquirir Hispania;

7) el olvido, en fovor del latín, del dialecto autóctono de cada tribu prerromana, y en general,

9) una gran prosperidad material y cultural simbolizada en la Pax Romana.

\section{Manifestaciones de la latinización}

El olvido, en favor del latín, del dialecto autóctono de cada pueblo prerromano constituye la latinización. Con referencia a la Península Ibérica, Rafael Lapesa acota: "La romanización de la Península fué (sic) lenta,.....pero tan intensa, que hizo desaparecer las lenguas anteriores, a excepción de la zona vasca". Por lo tanto, la adopción del idioma latino fue general, lo cual se manifiesta, entre otras cosas, en la imposición de nombres latinos a muchos lugares, con el fin de perpetuar la memoria de ilustres caudillos y emperadores:

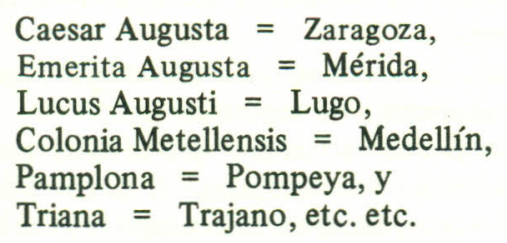

Transcurridos 199 años del desembarco de Cn. Escipión en Ampurias, Roma era la dueña absoluta de todo el territorio hispánico (con excepción de la parte vasca), cuya organización general fue concluida en el $14 \mathrm{a}$. Chr. $\mathrm{n}$.

Es natural que el latín haya comenzado a tener adeptos antes de dicha fecha, lo cual se resume del modo siguiente:

1) en el 171, había aborígenes que entendía y hablaban latín;
2) en el 127, éste ya era de uso común en la Bética;

3) en el 74, se daban poetas latinos en Córdoba;

4) durante las Guerras Civiles, también con teatro de acción en Hispania, el latín era habitualmente hablado en varias ciudades hispanas;

5) en el 45, desaparece el bilingüísmo de las monedas;

6) en el Siglo I p. Chr. n., según Estrabón y Tácito, los turdetanos ya sólo hablaban en latín, "No falta mucho, decía el primero, para que todos se convierran en romanos", y decía, además: "Los que viven a uno y otro lado del Baetis (Guadalquivir) se han cambiado totalmente al estimo romano, que ya no recuerdan su propio idioma". De hecho, la desaparición del ibero tuvo lugar en dicho siglo.

\section{Frutos de la latinización}

La incorporación lingüística de Hispania a la corriente idiomática emanada desde Roma se manifiesta de la forma detallada en seguida:

1) la penetración del alfabeto y de la escritura latinas;

2) la lectura de textos escritos en latín;

3) la escritura de toda clase de documentos, como actas notariales, imprecaciones a las divinidades, etc., y

4) la creación de obras literarias por parte de autores romanos nacidos en Hispania. ¿Existe otra manera mejor de manifestarse la latinización que con tales frutos?

El latín penetró en Hispania, como en la mayor parte de la futura Romania, en sus dos aspectos fundamentales: el clásico, para lo escrito, básicamente, y el vulgar o popular, para la comunicación oral. El primero tuvo en la escuela a su máximo propagador, y el segundo fue consecuencia directa del trato cotidiano.

VII. Circunstancias y motivos para el empleo $y$ triunfo de la lengua latina

1) Todos los actos, públicos y privados, de los romanos para con los aborígenes, y viceversa, fue en latín: el romano no se dignaría 
aprender ninguna forma lingüística aborigen; pero el hispano tenía que aprender el latín; de modo que las relaciones políticas, jurídicas, administrativas, comerciales, militares, y en general, diarias, eran en el idioma de los dominantes;

2) el latín era necesario para hacer carrera profesional;

3) el uso de dicho idioma encerraba toda clase de ventajas en el orden práctico, $y$, finalmente, asunto de mucha monta,

4) el latín tenía carácter de oficialidad, y por ende, era el idioma usado en las escuelas romanas; de modo que los niños hispanos, desde un principio, se encontraban impelidos a olvidar completamente su idioma patrio.

\section{La unidad hispana como beneficio directo de la romanización y latinización}

En las realizaciones que acabamos de enumerar, no hay que enmarcar la acción civilizadora de Roma como si se tratara de un asunto netamente negativo; esto es, sólo de sumisión, exterminio y explotación. Muchísimos aspectos de su labor fueron, y lo son, muy beneficiosos; entre estos, sobresale el exitoso cuerpo coherente que se logra obtener a partir de toda una heterogeneidad de pueblos, razas, culturas, lenguas, religiones y sistemas políticos.

Las destrucciones siguientes a la Caída del Imperio Romano (476) serán básicamente de los pueblos germanos, bárbaros que serán luego conquistados por la cultura romano-cristiana que pretendían destruir.

\section{La situación de Cantabria}

En el norte hispánico, siempre muy difícil de conquistar y someter, las Guerras Cántaro-Astures están enmarcadas en los aspectos generales de la romanización. Pero hubo uno de primer orden: la defensa, por parte de los romanos, en favor de ciertos pueblos romanizados (autrigones y turmogidas) contra los ataques feroces de los aborígenes norteños (avarigianos, avarianos, orgenamescios, etc.) a quienes se unen los vaccesos, cántabros y astures. Estos dos últimos pueblos, durante la conquista romana, dieron pruebas de un extraordinario amor hacia la libertad, principio moral que guiará a los castellanos, sucesores de los cántabros.
Según Floro, el espíritu bélico de éstos era el más encarnizado, pertinaz y molesto para sus vecinos.

Roma tomó tan en serio las guerras libradas en el norte que Augusto en persona -ya de Emperador- participó activamente del 26 al 25. Aún más; en toda su carrera bélica él sólo dirigió personalmente dos guerras, una de las cuales fue la Guerra Cántabro-Astur. Pero tales fueron sus preocupaciones, sinsabores y fatigas, que fue Agripa, su yerno, quien logró llevarlas a buen término.

\section{Efectos inmediatos de la victoria de Roma sobre cántabros y astures}

Una vez sometido el último reducto hispano, las consecuencias se manifestaron así:

1) merma de la población norteña y asentamiento, en las llanuras, de los sobrevivientes;

2) elaboración de un trazado de calzadas como factor material importante de adentramiento de los romanos. Desde este punto de vista, una vía de primer orden es la que se encuentra a orillas del río Ebro, la cual nacía en Tarragona e iba a morir en Castilla. Tal vía fue de mucha importancia para el comercio y de ella, además de Castilla, se beneficiaron, entre otras, Ilerda, Caesaraugusta y Calagurris;

3) permanencia de las legiones IV, VI y X;

4) creación de ciudades con base en asentamientos militares; por ejemplo, León es creación de la Legionem (de donde su nombre) VII Gemina, y Astorga, de Asturica Augusta;

5) introducción del sistema monetario, en vez de la economía de intercambio, y

6) asentamiento definitivo del idioma común hablado por los romanos: el Latín Vulgar. En el norte, también fue importante la labor desplegada por la Escuela de Sertorio, situada en Huesca, cuya finalidad primordial era educar romanamente a los jóvenes nativos.

Las Guerras Cántabro-Astures tuvieron una duración de 10 años (del 29 al 19). Luego de la finalización de dichas guerras, el latín vulgar ya estaría asentado y poco a poco se fue constituyendo en un latín hispánico con características norteñas, dadas las peculiaridades de los conquistadores y conquistados. Con el correr de los años y por circunstancias especiales inherentes a toda lengua 0 
dialecto, tal latín se va transformando, en forma imperceptible, en el dialecto castellano. Pero resulta muy difícil establecer detalles concretos de dicha transformación por la carencia de elementos escritos. En todo caso, es una realidad de que la traída del latín vulgar constituye la clave romance del castellano. Las regiones norteñas, aunque porco romanizadas, supieron mantener su latín, el cual se perpetuó en los diferentes dialectos, de los que procederán las distintas lenguas romances de la Península Ibérica.

\section{XI. ¿Cuándo se dejó de hablar latín en la Romania e Iberoromania?}

Esta pregunta implica otra: ¿cuándo comenzaron a ser hablados los diferentes romances? Las respuestas son hipotéticas y aproximativas; pues los idiomas no tienen inicio exacto ni término fijo; además, la conciencia colectiva, si existiera, no posee ninguna clarividencia en cuanto al final del latín y al principio del romance. Las únicas fuentes seguras son los documentos escritos, los cuales constituyen apreciaciones tardías. Existen, en todo caso, fechas y términos, suministrados por algunos filólogos y lingüistas, a los cuales se puede hacer sólo referencia:

Según algunos romanistas, el 476 , año de la Caída del Imperio Romano de Occidente, marca un terminus ad quem; dado que sus implicaciones sociopolíticas, con sus respectivos arrastres económicos, sociales y culturales, traen consigo el de las variedades idiomáticas: a una mayor unidad política, corresponde, casi siempre, otra de tipo lingüístico; debido, en parte, al interés de los políticos por la centralización.

Vidos, en su Manual de Lingüistica Románi$c a$, cap. III -que trata de las variedades del romance-dice: "Cuando en 476 con la caída del Imperio la unidad del latín se fragmentó definitivamente y ya no pudo desenvolver su función de lengua de comunicación y de enlace del Estado, la variedad del latín debía tener como consecuencia la variedad del romance. Ya no podemos hablar de latín vulgar o de prerrománico, románico común, etc., sino simplemente de románicos".

Straka, apoyado en la fonética comparada de las lenguas romances, y no en los documentos de la latinidad vulgar, fija el Siglo III, el cual es corroborado por Meillet; pues a partir de tal siglo se da un proceso de diferenciación latina en cada provincia imperial. Según el parecer de Ferdinand
Lot, en el Siglo VI ya no se habla latín. Walther von Wartburg recalca la importancia del superestrato germánico y opina que el latín popular dejó de ser hablado, desde el momento en que se efectuó la fusión de dicho superestrato con el latín, idioma base de los romances; es decir, en el momento en que los germanos invasores fueron asimilados por los latinoparlantes, fusión que se llevó a cabo en el Siglo VIII. Esta opinión es compartida por H. Fr. Müller y Iorgú Iordán.

Pero sólo con los documentos escritos se está en un terreno más seguro. En tal sentido, un año que no debe ser descuidado es el 813 , fecha del Concilio de Tours, aunque el mandato de no usar más el latín en el culto es el resultado obvio de la práctica del romance.

Durante la Reforma Carolingia, se pusieron de manifiesto las diferencias existentes entre el latín y romance y se tomó conciencia de como el primero ya no era lo que se pensaba; que por lo tanto, era necesario reiniciar su estudio. La proliferación de glosas romances, en los Siglos VIII y IX, inducen a la conclusión de que algo dificultaba la comprensión de ciertos términos y giros latinos y de que era imperioso aclararlos por medios de los respectivos sinónimos, labor que llevan a cabo, entre otros, los glosadores del Aemilianensis y del Silensis en la Península Ibérica.

Como conclusión de este apartado, podríamos fijar el lapso del Siglo V al VIII como período aproximativo para suponer el nacimiento, a partir del latín vulgar, de las variedades románicas. De hecho, en tal período comienzan a desaparecer los textos de la latinidad vulgar, y en caso de escribirse, salen a la luz salpicados de formas romances: vocalismo románico, aparición del artículo, fusión del nominativo en el acusativo, futuro perifrástico, para nombrar sólo lo esencial. En Francia, como ejemplo de tal latín, está el merovingio, y en España, el de las actas notariales.

¿Cuándo desapareció el latín vulgar y aparecieron las lenguas romances?

No existen fechas precisas; pues la transformación del latín popular a los dialectos romances se hizo en etapas sucesivas no discontinuas, de las cuales ninguna es definitiva, lo que explica el cambio imperceptible del latín al neolatín.

La unidad latina, evidente en los Siglos I y II, se disgregó sin que nadie se diera cuenta, una vez que se perdió el vínculo con la Urbe, ante todo, por la acción bélica de los germanos. Entonces el latín vulgar de cada lugar comenzó a acentuar sus peculiaridades latentes, producto del 
aislamento en que cayeron las diferentes provincias del imperio, con el consiguiente acrecentamiento de las fuerzas disociadoras entre ellas y la capital imperial, de lo cual también es producto el desvanecimiento del sistema administrativo, jurídico, político y escolar creados con tanto celo por Roma.

De modo que la descentralización y falta de cohesión del otrora grandioso Imperio Romano incidieron, en forma directa, sobre el latín unitario. En forma indirecta incidieron los siguientes factores: el tipo de latín llegado a cada región, la época y el modo de la romanización, las diferencias culturales y sociales de los romanizadores, los distintos sustratos idiomáticos, y más tarde, las sedes episcopales instituidas por la Iglesia en reemplazo de los conventos jurídicos (divisiones administrativas romanas).

Habiéndose fraccionado el latín, desde el Siglo V al VIII, en una gran cantidad de formas dialectales, en dicho latín se producen las innovaciones fonéticas, morfológicas, lexicales y sintácticas propias de las hablas locales hispanas, las cuales encontraban una mayor acentuación por causa de las enormes distancias y la falta de medios de comunicación.

\section{Referencia al período y romance visigóticos (412-711)}

La disgregación del latín tuvo su punto culminante en la época visigótica, llamada así por la ocupación efectuada por los visigodos -de estirpe germánica - de gran parte de la Península Ibérica. Por lo tanto, en tal época tuvo lugar la transición del latín vulgar hacia los diferentes romances hispánicos.

¿Qué razones tuvieron los visigodos para no imponer su dialecto - lo contrario de los francos en Galia - ya que eran los vencedores y amos de la Hispania de entonces?

Una razón podría ser su sentimiento de inferioridad ante el legado de Roma: su cultura y su lengua, las cuales ya les eran conocidas, debido a sus continuas correrías por el Imperio Romano.

De modo que no les fue difícil abandonar su dialecto germánico y asimilar el románico, que desde entonces quedaba impregnado con préstamos visigodos. Llegaron a más: se consideran los herederos y defensores de la herencia romana, cuyo recuerdo seguirá latente en Toledo, Asturias y León. Y el hecho de haber mantenido la denominación histórico-geográfica de Hispania, no cambiada por el de un posible nombre de Gotia, ¿no es acaso elocuente de la sinceridad de su conversión cultural, lingüística y religiosa? Recordemos que al otro lado de los Pirineos, el nombre de Galía sí fue sustituido por el de Frantia (del pueblo franco).

Desde el punto de vista de la lengua, el habla de la Hispania Visigoda es el romance-visigótico, un latín hispánico evolucionado y fusionado con algunas formas (de superestrato) visigóticas.

Tal tipo de romance es entendido por Menéndez Pidal del siguiente modo: "El romance más común, en la época visigótica, no presentaba como caracteres propios los que después habían de llegar a ser distintivos de la lengua española oficial. Por el contrario, ofrecía los rasgos en que hoy el Occidente y el Levante se apartan del castellano para conformarse con otros romances extranjeros, porque esos rasgos se hallaban también en todo el territorio mozárabe. Tales son la $l l$, y no la $j$ castellana, en fillo y demás voces análogas; la frecuente diptongación ante yod, por ejemplo, en uello, en vez del castellano ojo; la $f$ y no la $h$ castellana, en fazer, famne, por 'hacer', 'hombre'; la it, y no la ch castellana, en voces como feito, muito; la g-inicial en casos como genairo por 'enero'. Todos estos caracteres hallábanse extendidos por la mayoría del reino godo...".

Explicamos un poco más lo anterior, basados en un solo ejemplo: Con la cita precedente, el autor hace referencia a la unidad idiomática existente en el período en referencia, la cual se prolongará hasta el definitivo asentamiento del castellano. Si se comparan palabras castellanas, aún actuales, con determinadas palabras homólogas del iberorromance y del romance en general, notamos cómo el castellano se aparta del sendero común para seguir una vía distinta. El ejemplo tomado en consideración es el verbo latino facere, cuya/f-/ se mantiene en todos los romances, excepto en castellano que la transforma en $/ \mathrm{h}-/$ : castellano, hacer; francés, faire; italiano, fare; gallego-portugués, fazer, y catalán, fer, etc.

El romance visigótico presentaba algunas formas romances unitarias, las cuales se continúan en el mozárabe y luego en el judío sefardita, y que fueron abolidas o cambiadas por el castellano, un intruso en el sistema iberorrománico de entonces.

\section{Inicio de la conquista y reconquista}

Se inserta, seguidamente, un brevísimo relato sobre la conquista y reconquista del suelo 
hispánico; pues el nacimiento y superposición del castellano están muy condicionados con tales eventos:

\section{a) La Conquista Arabe}

En julio del 711, tuvo lugar la famosa batalla sobre el Rio Guadalete, por la que Tariq, al mando de unos 12.000 súbditos (árabes, bereberes y sirios), usurpó el trono al último rey visigodo, Don Rodrigo.

El episodio fue motivo de varias leyendas. La más conocida es la relacionada con Florinda (la Cava), hija de Julián, conde de Ceuta, quien se dio por ofendido por el ultraje perpetrado, contra su hija, por el susodicho rey.

Se dice que tanto el descontento del conde como de algunos visigodos y judíos, seguidores de Witiza, fue la casua directa que encendió la chispa, y por ende, ocasionó la apertura de las puertas del mediodía peninsular, con el consiguiente adentramiento musulmán en territorio ibérico, cuya ocupación, casi total -exceptuados los valles cantábricos y pirinaicos- es un hecho cumplido en el 716. Tal ocupación, con los reveses del caso, se prolongará hasta el 2 de enero de 1492, en cuya fecha Isabel de Castilla y Fernando de Aragón penetran los umbrales de la Alhambra.

La consecuencia lingüística de la llegada árabe-bereber se manifiesta en el aislamiento en que quedarán sumidos los románico-visigodos, llamados ahora mozárabes, rodeados de un mundo cultural muy extraño, el musulmán, lo cual causa el estancamiento del dialecto mozárabe y la penetración de arabismos en los romances peninsulares.

\section{b) La Reconquista Hispana}

Mas en el 718, un pequeño grupo de visigodos derrotados, pero muy vinculados con su antiguo régimen y animados por el espíritu de libertad, al mando de Pelayo (718-737), yerno de Alfonso I de Asturias, emprende la retirada hacia el norte y luego la resistencia, concretamente en las regiones montañosas galaicas y asturianas, donde Covadonga marca el punto inicial reconquistador, continuado 20 años después por Alfonso I, quien se vale del hambre y de la rebelión entre los moros.

Los primeros cristianos visigodos que inician su expansión por el territorio, a partir del norte, constituyen una nobleza que desea restaurar su antiguo reino y dominio perdidos.
Pero los verdaderos iniciadores de la empresa reconquistadora son los astures y cántabros.

Fruto de la expansión y adueñamiento del territorio hispano es la creación de pequeños núcleos cristiano-románicos, a saber, los condados y reinos entre los que sobresalen el Condado de Castilla, el Reino de Asturias-León y el Reino de Navarra. Todos forman entidades político-administrativas con un fin bastante definido: la expulsión de los moros del patrio suelo.

La fundación del primer reino, el de Asturias, data del 722. Oviedo, su capital, tuvo que ser trasladada hacia León, durante el reinado de Ordoño II (914-722) por encontrarse muy alejado, hacia el norte, y por ser sus puertos muy empinados.

Desde el 912, Asturias-León es considerada como poseedora de la antigua herencia de Toledo; por tal motivo, se constituye en el foco de la resistencia antimusulmana y como exaltadora de los ideales del neogotismo.

De los condados, Castilla fue el que más se destacó por un siglo de luchas fronterizas (791-912) y por el otro siglo de batallas (1085-1212) llevadas a cabo contra otros estados cristianos, sobre todo contra el centro astur-leonés, que culminó con su anexión en el 1230; pues los reyes leoneses ya no estaban en condiciones de mantener la preciada unidad de su reino; en efecto, éste quedó muy perturbado por las derrotas que le había infringido Almanzor, las cuales tuvieron su punto crítico con dos saqueos. Tal situación fue aprovechada por Castilla para declararse independiente y darle vuelta a la medalla: el impulso reconquistador godo -astur-leonés se traslada hacia Castilla después de anexarse a algunos condados pertenecientes a Oviedo y a León. Había nacido un espíritu antileonés y antiimperial en Vasconia (Navarra) y en Cantabria (Castilla) que tuvo como consecuencia el resquebrajamiento de la unidad imperial preconizada por León. Bajo Fernando I (1035-1065) tiene lugar el triunfo, en Castilla, de la dinastía vascona y la entrada de Castilla en la política hispana en un primer plano, afirmada ya como reino (1037), cuya consolidación se lleva a cabo en 1217, bajo Fernando III, padre de Alfonso, el Sabio. La gloriosa victoria de Castilla de las Navas de Tolosa (1212) puso de manifiesto la superioridad de las armas castellanas y relegó a León en un segundo plano. En adelante, sin los obstáculos de León, Castilla mantendrá un papel rector en los destinos políticos y militares de la península.

Desde entonces, el dialecto leonés quedó 
relegado a una forma de compromiso entre el gallego, el castellano y el mozárabe; compromiso corroborado, en parte, por su falta de producción literaria; además, el ser un dialecto no propenso hacia las innovaciones y con miradas al pasado, lo contrario del castellano, atrajo su ruina.

Demográficamente, en plena reconquista, Hispana estaba integrada por una población muy heterogénea formada por románico-visigodos (mozárabes), árabes, bereberes, sirios, muladíes, judíos, galaicos, astures, cántabros, vascos y demás pueblos montañeses del norte, entre los que se cuentan los castellanos como un producto híbrido aún no existente en el período visigótico.

\section{Resumen histórico sobre la reconquista}

La reconquista hispánica, suceso bélico causante de la expansión del castellano y consiguiente abolición de otras formas dialectales romances, la bosquejamos del siguiente modo:

1. Siglo $I X$ : son reconquistados los territorios hasta la línea del Arlazón;

2. Siglo $X$ : se toma la línea del río Duero; por lo tanto, toda Castilla la Vieja es ocupada;

3. Siglo $X I$ : la reconquista se extiende hasta la línea del Tajo, con la consiguiente ocupación de Toledo, en 1085, por Alfonso VI, Rey de Castilla y de Valencia por Rodrigo Díaz de Vivar, el Cid Campeador;

4. Siglo XII: Fernando III ocupa la línea del Guadalquivir;

5. Siglo XIII: la Batalla de las Navas de Tolosa, del 1212, despeja el camino hacia Andalucía y

6. Siglo $X V$; los moros son definitivamente arrojados de la Península Ibérica luego de la Conquista de Granada de 1492.

El proceso de la reconquista es un triunfo total y definitivo de las armas castellanas en unión con los otros reinos hispánicos. Constituye un éxito definitivo de las primeras intenciones de Pelayo, cuando se refugió en el norte para hacerle frente, de primero, al invasor; y engendra una consciencia colectiva del pueblo español con una unidad política e idiomática, por y para la mayor parte de Hispania.

\section{Origen de Castilla}

\section{a) breve introducción}

Recordemos que la conquista romana de la Península Ibérica finalizó definitivamente el 19 a. Chr., cuando Augusto, representado por Agripa, yerno suyo, sometió el último reducto hispánico, a saber, Asturias y Cantabria, después de casi 200 años de difíciles luchas entre romanos e hispanos; que inmediatamente Cantabria, Gallaecia y Asturica pasaron a formar parte de la Hispania Citerior; que en dichas regiones norteñas se encuentran asentados los vascos, cuya romanización fue tardía, lenta y débil; que el vasco nunca fue reemplazo por el latín, y sólo parcialmente por el romance; que entre la caída del Imperio Romano y la del Reino Visigodo se interpuso el segundo, de origen y aportes germánicos, pero muy asimilado a la cultura romana; que durante la llegada de Rodrigo, último rey visigodo, a Cantabria y al territorio vasco, tanto la primera como el segundo eran siempre rebeldes a todo tipo de dominio extranjero; y que fue bajo Pelayo, primer jefe antiislámico, que Cantabria logró asestarles, en Covadonga, el primer golpe a los invasores árabes.

\section{b) origen histórico-geográfico}

El origen de Castilla, además de muy humilde ("un pequeño rincón") según la alusión del Poema de Fernán González, es, en cierto sentido, artificial: un producto de reconquista y asentamiento de poblaciones. Así fue el origen de Amaya (repoblada en el 860), cabecera de Castilla - una fortaleza natural- cuya repoblación fue llevada a cabo por el conde Rodrigo, según órdenes del rey ovetense.

Bajo Alfonso I, el reino de Asturias, el cual se considera la continuación norteña del inexistente reino visigótico de Toledo, establece hacia el sur, con el Duero como foso, una marca fronteriza a oriente del reino astur-leonés; esto es, un puesto externo, un "hinterland" (zona de retaguardia) que le debe servir al norte como barrera protectora contra las incursiones conquistadoras musulmanas. Tal lugar tendrá como misión principal defender y asegurar el peligroso Paso del Pancorvo.

El conde Rodrigo fue el primer representante real, designado y puesto por Ordoño I, hijo de Ramiro II, para llevar a cabo tal difícil cometido; pues la corona quiere, como delegado directo, un conde, el cual tiene que habitar la parte sur de los 
Montes Cantábricos, frontera con el mundo árabe. Rodrigo cumplió, en calidad de conde, del 852 al 873; más no se sabe de él.

$\mathrm{Su}$ hijo, Diego Rodríguez, representó un momento brillante de la expansión castellana, el cual, de conquista en conquista, logró finalmente adueñarse del preciado Paso del Pancorvo y luego, en su expansión, continuó erigiendo más y más castillos o defensas militares.

Pero su acción despierta los celos del rey de Oviedo, Alfonso III, quien lo mandó matar en Cornuta. Desde entonces, la familia del conde Rodrigo pierde toda clase de influencias, y Castilla cae en el olvido durante medio siglo. Mas el poder ya estaba consolidado, y los norteños, esa gente indomable, no echarán pie atrás. Todo lo contrario: continúan su lucha, no obstante ciertas vicisitudes negativas; lucha, no sólo contra los musulmanes, sino contra el mismo León, capital del nuevo reino visigodo.

El engrandecimiento de Castilla continuará bajo García Fernández y Sancho García. Al morir el infante García Sánchez (1029), el condado pasó a manos de Sancho el Mayor, de la dinastía navarra, iniciada con Fernando I. Tal dinastía llevará Castilla a constituirse en el máximo estado dirigente de la España medioeval cristiana, proceso que culmina con la anexión del mismo León. A partir de entonces, la vía estaba ya expedita para la reconquista total.

El condado de Castilla tuvo su nacimiento en la antigua Vardulia, en los valles sureños, al pie y prolongación de la Cordillera Cantábrica Romana, en uno de los extremos de la Provincia Tarraconensis al limitar con el área vasca de Navarra.

En sus inicios comprendía: Campó, la parte norte de la Provincia de Burgos, la Oca, la región oriental de Gallaecia, la Cantabria propiamente y los cursos superiores del Alto Ebro y del Alto Pisuerga, al occidente del Valle de Mena, en la parte alta del río Trueba. Por lo tanto, Castilla constituye una zona limítrofe, "una encrucijada de tierras diferentes... sobre la raza que separó a los autrigones de los de los cántabros”, según Sánchez Albornoz; una zona enclavada en tres territorios diferentes correspondientes a sendas provincias romanas: la Gallaecia (montañas, prados y mar de Santander; el Alto Pisuega y el Alto Ebro); la Tarraconensis (Alaba y Dureba) y la Cartaginensis (Burgos y Osma), según Ramón Menéndez Pidal. Por consiguiente, su especial situación le proporciona tendencias y características de sus vecinos.

\section{c) Origen étnico-social}

Los várdulos -de donde procede el nombre de Vardulia, como era conocida Castilla - fueron impelidos por los vascos desde el río Arlazón hasta el norte de la región burgalesa. Luego llegaron también los mismos vascos, los cántabros y otros pueblos montañeses procedentes de Liébana, la Montaña, Autrigonia, algunos visigodos del sur, que habían sido liberados por el rey de Asturias, y finalmente, algunos mozárabes que habían logrado escapar de los musulmanes.

Con elemento tan heterogéneo se fundó en Vardulia (850) el núcleo primitivo del Condado de Castilla, formada por pueblos semirromanizados (várdulos, cántabros y vascos) y romanizados (visigodos y mozárabes), cuyo elemento predominante es el cántabro, pueblo de origen indoeuropeo, poseedor de un sustrato lingüístico parecido al del vasco.

Desde la perspectiva social, Castilla estaba compuesta de pequeños propietarios libres, y de una nobleza modesta pero potente, configurada por los caballeros; todos regidos por el derecho consuetudinario.

\section{d) Origen toponímico}

El nombre de Castilla existe desde el año 800 bajo la denominación latina de Territorium Castellae; pues el territorio várdulo, a cada paso de avance, se señaló por la erección de un castillo; de aquí el nombre más conocido de Castilla, id est, Tierra de Castillos, voz procedente del neutro latino plural (castella) del sustantivo castellum. La mezcla de sus habitantes son los castellanos.

También se encuentra documentado el sinónimo de Vardulies: "Vardulies quin nunc vocitatur Castellae".

El nombre de Castillo no les era desconocido a los historiadores árabes, quienes la llamaban en su lengua "al-Qila" (con $-a$ colectivo, como en latín).

Vardulia, la tierra yerma protegida por el foso del Duero, logra en el 931, bajo Fernán González, desprenderse de León y unificar otros condados como Burgos, Alava, Lara, Cerezo, etc., y el conde entonces se titulará "Comes totius Castellae".

\section{e) Breve conclusión}

Es Castilla, pues, un producto híbrido en su 
origen, pero unitario en su propósito y proyección futura, dados su espíritu irdependiente e intereses político-militares bastantes definidos: rebeldía contra todo poder central y determinación de acabar con los africanos. Además, sus ideales, no neogóticos, contrastan con los preconizados por Toledo, Asturias y León, que más bien se vieron envueltos en el torbellino castellano al seguir los intereses e ideales de Castilla.

Pero su situación de avanzada bélica; expuesta, por lo tanto, a toda clase de vicisitudes; su dependencia inicial, de León, su oposición y lucha contra el reino astur-leonés y su estado de beligerancia continua contra los moros, hasta no haberlos expulsado en modo definitivo, muestran el ahínco con que Castilla supo, en forma no fácil ni muelle, llevar a cabo su cometido.

\section{Origen del idioma de los primeros castella- nos}

¿Cómo se expresarían los primeros moradores heterogéneos de la Vardulia en su propia lengua? Con toda probabilidad, empleaban un latín coloquial con cambios anteriores a su disgragación dialectal peninsular: un latín muy romanceado, propio de vascos y cántabros semirromanizados. ¿Usarían tal vez una variedad asturiano-leonés-visigótica-vasca? o ¿Era tal variedad de origen galaica, según mención de Peregrín Otero, quien emparienta el dialecto castellano primigenio con su vecino, el dialecto leonés, ambos desprendidos del tronco galaico? ¿En realidad la variedad castellana tuvo origen en un rincón rústico y humilde, en un principio muy reducido geográfica y humanamente; esto es, en la Antigua Cantabria o Vardulia? No nos atrevemos a dar ninguna respuesta.

Sí es probable que dicha variedad asturleonés, galaica, o lo que fuese, poseía más estridencias, rusticidad y particularidades que el dialecto de Oviedo o el de León, continuadores, en el norte, del romance visigodo; por lo tanto, más pulidos y urbanos que el de los rústicos cántabros, pobladores de la Peña de Amaya, del Pancorvo y de los valles de los cursos superiores del Ebro y del Pisuerga. Su idioma, metafóricamente, resonaría como trompeta con tambor, para repetir las palabras del Cantar de Almería: "Illorum lingua resonat quasi tympano tuba".

\section{Propagación del idioma de los primeros castellanos}

El habla castellana inicia una lucha concomitante con la política y luego continuará su lucha en la modalidad burgalesa contra las demás variedades, continuadores del latín no clásico empleado en suelo hispánico, desde el momento en que abandona su nido materno y se lanza victoriosa hacia la reconquista y unificación de casi todos los reinos y dialectos hasta culminar con la adopción del romance castellano, sin dejar el original: leonés, ovetense, riojano, aragonés, etc.

En la segunda mitad del Siglo XI, las modalidades propias del castellano comienzan a expandirse por el área ibérica , una vez debilitado el Reino de Navarra y perdida la hegemonía de León. Entonces la supremacía político-militar y lingüística del castellano arrastra consigo la extensión de su dialecto, que, como fruto de la reconquista, avanza hacia el sur en forma de abanico.

El castellano representa entonces un nuevo estado de lengua, la cual continúa o y desarrolla nuevos aspectos diferenciales y característicos, de acuerdo con su historia propia y con los préstamos de otros dialectos y lenguas extranjeros.

¿Cómo creció el dialecto castellano desde su humilde cuna hasta convertirse en una lengua universal? Manuel Seco, en su Gramática Esencial del Español, da la respuesta: "La particular situación de aquella primera Castilla, tierra de fortaleza, línea defensiva de los reyes de León, expuesta constantemente al peligro del enemigo moro, constituida por gentes que -a diferencia de sus señores, los asturianos-leoneses- no se sentían ligadas a una tradición romano-visigoda, dio a los castellanos un espíritu revolucionario, independiente y combativo, que se reflejó en su conducta política, en sus costumbres y en su lenguaje.

El dialecto castellano presentaba una personalidad muy marcada frente a los dialectos peninsulares. Se formaba en una zona más débilmente romanizada que la de éstos, y por tanto estaba más vivo en él el recuerdo de las viejas lenguas, alguna de las cuales todavía se hablaba en las comarcas vecinas"...

El avance político-militar, y luego lingüístico, de Castilla, es consecuencia, entre otros, de la bravura, empuje y espíritu de rebeldía de independencia de sus moradores, los castellanos (aunque tal concepción suene a nacionalismo y sea una especie de preludio a "España es diferente") 
quienes se administraban justicia por el Fuero de los Albedrios, su fuero autóctono y consuetudinario, y no por el antiguo Fuero Juzgo ("Forum Judicum"). Más bien fue al revés: León se castellaniza.

El castellano, primitivo dialecto latino de Vardulia (Castilla), logró imponerse como idioma nacional de España, contra todas las formas romances, exceptuado el judeo-español.

\section{Situación lingü ística iberrománica paralela al castellano primitivo}

El latín vulgar importado por los romanos hacia la Península Ibérica comenzó a tener un proceso de romanceamiento que originó al protorromance ibérico, el cual, en la época mozárabe, se dividió en mozárabe propiamente, o romance sur-ibérico y en romance nord-ibérico. Este, a su vez, dio origen al iberorromance occidental (gallego-portugués), iberorromance central (castellano y leonés) y al iberromance oriental (catalán).

En la parte musulmana, el árabe constituída la lengua de la cultura, de la administración, de la religión (por lo tanto, del Corán) y del campo jurídico. El mozárabe, al menos en las grandes ciudades, fue el heredero directo del romance visigótico.

El latín clásico-medioeval de entonces había caído muy bajo en su prestigio, tanto que Alvaro exclamaba: "Heu proh dolor! Linguam suam nesciunt christiani"; pues el latín escrito (notarial y eclesiástico) que seguían usando algunos pocos era un "latinum obscurum", un "latinum circa romancium" - un latín pobre y con formas propias del romance- quizás, parecido al mal latín empleado en la época merovingia francesa; por ejemplo, al de Gregorio de Tours, escritor sin pretensiones literarias, 0 al de los notarios de entonces. Era pues, un latín sin movimiento y cuajado de "errores", los cuales eran tomados de la lengua hablada: mal uso de grafías, confusión en la conjugación y declinación, pronombres antecesores del artículo románico, desaparición del género neutro latino, uso prolifuo de las preposiciones en lugar del sistema flexional característico de las lenguas indoeuropeas y menos empleo de cierto tipo de oraciones muy propias del latín clásico, tales como el acusativo con infinitivo, el ablativo absoluto, etc.; un sistema descompuesto del idioma latino en la Romania del Siglo IV al X.
Tal es la situación lingüística, para resumir, que se configura en la Península Ibérica en el Siglo $\mathrm{X}$, por ejemplo: paralelamente al árabe, por un lado, y al latín medieval, por el otro, se estaban desarrollando, a partir del latín, las siguientes modalidades usadas en el norte: gallego-portugués, asturiano-leonés, castellano, navarro aragonés y el catalán; todos los cuales, constituyen la tercera parte de la Península Ibérica. Más abajo de la línea divisoria de tales formas, se extendían, por el Anadaluz, los dialectos mozárabes, que sucumbirán ante el avance del castellano, pero que según algunos tuvieron su continuación natural en el judeo-español. Contra la romanicidad anterior, forma casa a parte el vascuense o éuskara, el cual no naufragó en el olvido, tal vez, por la independencia y aislamiento de sus moradores, los vascos.

\section{La antigua unidad románico-hispánica}

En la Península Ibérica reinaba, desde la época visigótica, continuando con la época mozárabe, hasta concluir con el asentamiento del castellano, una cierta unidad lingüístico-románica entre las diferentes maneras de expresión derivadas del latín. Los siguientes ejemplos, extractados de la Fragmentación Lingüistica de la Romania, de Walther von Wartburg, nos presentan tal estado unitario y su confrontación con el castellano:

Pues bien, dicha unidad fue rota por el dialecto castellano (según se puede obserar en la cuarta línea vertical) que en su mismo rincón de origen poseía tales modalidades diferenciadoras de los demás dialectos peninsulares.

De este modo se propagaron, entre otras, las características subrayadas en el cuadro anterior, correspondientes a la fila vertical (castellano) entre los siglos XII y XV, que le dan una nota especial al castellano dentro del conjunto iberrománico y hasta románico; pues tanto el francés como el italiano, por ej., presentan, en tales casos, más parecido con los otros dialectos peninsulares.

Así, el castellano, al acaparar el puesto de los dialectos mozárabes del sur y el de los dialectos leoneses y navarro-aragoneses, todos indecisos, rompió la antigua unidad iberromance, en forma de una cuñada clavada de norte a sur que cortó el lazo existente entre el oriente y el occidente hispano: "La nota diferencial castellana obra como una cuña que, clavada al Norte, rompe la antigua unidad de ciertos caracteres comunes románicos antes extendidos por la Península y penetra hasta 


$\begin{array}{lllllll} & \text { Galicia-Portugal } & \text { León } & \text { CASTILLA } & \text { Aragón } & \text { Cataluña } & \text { Mozárabe } \\ q+e, i: & \text { giesta } & \text { ienesta } & \text { hiniesta } & \text { (germano) } & \text { giniesta } & \text { yenesta } \\ j+e, i: & \text { janeiro } & & \text { enero } & \text { geitar } & \text { ginar } & \text { yenair } \\ f-: & & & & & & \\ -l i-: & \text { filho } & \text { fillo } & \text { hijo } & \text { fillo } & \text { fill } & \text { filyo } \\ -c l-: & \text { olho } & \text { uello } & \text { ojo } & \text { uello } & \text { ull } & \text { uelyo } \\ -c t-: & \text { leite } & \text { leite } & \text { leche } & \text { leite } & l l \text { et } & \text { leite } \\ -l t-: & \text { escuita } & \text { escuita } & \text { escucha } & \text { escuita } & \text { escolta } & \\ -s c i-: & \text { faixa } & \text { faxa } & \text { haza } & \text { faxa } & \text { faxa } & \text { fasa }\end{array}$

Andalucía escindiendo algunas originaria uniformidad dialectal, descuajando los primitivos caracteres lingüísticos desde el Duero a Gibraltar, esto es, borrando los dialectos mozárabes y en gran parte también los leoneses y aragoneses, y ensanchando cada vez más su acción del Norte al Sur para implantar la modalidad especial lingüística nacida en el rincón cántabro". Así expresa Menéndez Pidal la nota diferencial del dialecto castellano, cuya expansión causa un hecho singular: Toledo no acepta el dialecto de Oviedo ni de León, sino el de los castellanos, lo cual presenta una notables situación; pues desde la caída de Toledo, el castellano llegará a ser la lengua oficial de las cancillerías reales de Hispania, y por lo tanto, español.

Expone el autor en referencia:..."El gran empuje que Castilla dio a la reconquista de Toledo o por Anaducía, el gran desarrollo de la literatura y cultura castellana trajeron consigo la propagación del dialecto castellano, antes poco difundido".

El castellano, pues, logra imponerse sobre las demás formas dialectales del mozárabe, reduce el leonés y aragonés y se abre paso entre el gallego-portugués y el catalán, lo que trae como consecuencia el despadazamiento de la antigua unidad lingüística de la Península Ibérica dada desde el latín al visigótico; pero a la vez, logra una mayor cohesión y extensión que los anteriores; ya que se convierte en la más importante lengua de tal península, el español moderno, un instrumento lingüístico generalizado, primero nacional y luego internacional.
A los reinos de León y Aragón no les quedó otra alternativa que aceptar el castellano por su prestigio, individualidad, mayores dotes evolutivas y mejor selección y seguridad lingüísticas.

En otro lugar, Menéndez Pidal explica la causa del mozárabe, leonés y navarro-aragonés:..."La razón principal de esta diferencia (lingüística)... es que en León, en Navarra o entre los mozárabes, la lengua materna y familiar vivía en completo desprestigio frente al latín oficial, desamparada de todo cultivo literario o noble. Por el contrario, la Castilla del siglo X debía de estimar su lengua propia al par de la latina o más...y así indudablemente la empleaba en esa producción épica de interés político y social más pareciada y más cultivada que las crónica en latín. Lo cierto es que, viviendo Fernán González, existía ya en Castilla una norma prevaleciente de hablar... Mientras los documentos escritos en León y en Aragón vacilan mucho entre varias formas gramaticales, los documentos castellanos antiguos adoptan ya con seguro acierto aquellas formas que dijimos, las cuales andando el tiempo iban a difundirse también por el dialecto leonés y por el aragonés"

... "En suma, la Castilla primitiva en su lenguaje, lo mismo que en la politica y la guerra, lo mismo que en el derecho, se adelanta a cumplir una evolución que estaba destinada a triunfar"...

En resumen; el conjunto de dialectos procedentes del latín hablado, tuvo, en Castilla la Vieja, uno que logró sobresalir, el cual invadió la región burgalesa en el 884 por obra del conde castellano, 
Diego Rodríguez; luego el castellano se impone en la Rioja (lugar del priner texto escrito en romance), entre otras regiones.

En la región burgalesa se forja y extiende un castellano más clarc, unificado, seguro y evolucionado, que fue el que venció en Toledo en 1085, donde adquiere soltura y pulimento por la pluma del Rey Sabio. Otra vez, los rústicos hablantes norteños se mezclaron con los más cultivados del centro, cuando Toledo fue reconquistada, en la fecha anterior, por Alfonso VI. Poco después comienza a vislumbrarse una cierta uniformidad de la lengua escrita de dicha ciudad bajo la modalidad castellana hasta su imposición por obra de la clara égida de Alfonso el Sabio (1221-1282) como lengua oficial de la cancillería real, de las actas notariales, y sobre todo, de la literatura, con la consiguiente sustitución del latín medieval. En adelante, Castilla la Nueva superará, en literatura, a Castilla la Vieja.

Se obtiene, entonces, una nivelación lingüística del reino por medio del habla toledana castellanizada pero sin exclusión de las características burgalesas; tal nivelación lingüística sirvió luego de modelo, como también lo fueron el portugués y el catalán, en sus respectivas zonas, por motivo de intereses centrífugos. En resumen. la estandarización del castellano se obtuvo por los siguientes motivos:

1. la conquista de Toledo en $\mathbf{1 0 8 5}$,

2. el empleo del castellano como lengua cancilleresca, y

3. el aprecio popular por la poesía épica escrita en esta lengua.

\section{Olas de la expansión castellana}

La iniciativa y acción bélica de los castellanos tuvieron un avance concomitante con su forma de expresión, el castellano, desde su pequeño núcleo original. Dicho avance siguió rumbos diferentes, los cuales se irradiaron sobre Burgos y gran parte de Hispania en 3 distintas olas que encuentran su relación directa con las tres lenguas romances peninsulares: el castellano, portugués y catalán:

La primera, hacia el sur, donde el dialecto castellano acarrea la desaparición ¿o absorción? de los ya empobrecidos y hasta raquíticos dialectos mozárabes, los cuales no le opusieron ninguna resistencia y se dejaron absorver por los conquista- dores. Menéndez Pidal nos proporciona el motivo: “...El castellano se va sobreponiendo al mozárabe, la causa es que, mientras los castellanos disponían de un dialecto que gozaba de gran cultivo literario, los mozárabes, por un mal entendido orgullo ciudadano, se encastillaron en usar el árabe como su lengua de escritrua, con lo que condenaron a extinción ineitable su viejo dialecto romance".

Pero en contra de la desaparición total del mozárabe se manifiesta Carlos Peregrín Otero, quien piensa que el romance mozárabe tuvo su continuación en el español (no castellano) medieval, el cual, a su vez, tiene su continuación normal en el judío sefardita (español propiamente dicho).

La segunda, hacia el oeste, en dirección de León hasta los bordes con Galicia y Lusitania, donde quedan relegadas algunas viejas formas lingüísticas de las que procederá el gallego-portugués.

Y la tercera, hacia el este, la cual desaloja las formas dialectales del catalano-aragonés extendidas hasta Navarra y la Rioja (lugar del Emilianense $60)$. En la parte no alcanzada por el castellano se extiende el territorio catalano.

Si nos trazamos fechas imaginarias en nuestra mente, que son continuaciones seguidas de líneas, notamos como el castellano nace en el extremo noreste de la Península Ibérica, en Galicia, al sur de Asturias, y luego como se expande un poco hacia el centro de León, se desvía hacia el lado de la Rioja y continúa hacia Burgos y el resto de Castilla la Vieja; en Toledo, ya casi en el centro peninsular, se trirramifica hacia el oeste, centrooeste-sur y sureste. Lo restante es fruto de la estandarización mencionada.

XXI. Períodos, en sus orígenes, en la formación del romance hispano:

I. periodo. Corresponde al asentamiento del latín vulgar en la Península Ibérica sobre diferentes formas de las lenguas de sustrato. Hemos de suponer que dicho latín desarrolló voces y formas propias que no se dieron en ningún otro lado de la Romania, tales como, sólo por citar:

a) Arcaismos: res nata $>$ cosa nada $>$ nada; quaerere $>$ querer; fabulare $>$ hablar; cuius $>$ cuyo; cova $>$ cueva ( y no del clásico, cava); percuntari $>$ preguntar; campsare $>$ cansar; mustaceus $>$ mostacho; salire (brotar de una planta) $>$ salir; triticum $>$ trigo; trapetum $>$ trapiche, etc. Tales arcaísmos son producto de la penetración temprana del latín en Hispania. 
b) Neologismos: fartus $>$ harto, perna $>$ pierna, serrare $>$ cerrar; expergitare $>$ despertar; formaceus $>$ hormazo; altarium $>$ otero; cibatum $>$ cebada; appacare $>$ apagar; callare $>$ callar; maneana $>$ mañana; rivus $>$ río.

Los neologismos siguientes son documentados por Isidoro de Sevilla: catenatum > candado; colomellus $>$ colmillo; serralia $>$ cerraja, y cattus $>$ gato.

II. periodo. Se extiende de1 414 al 711 ; es por lo tanto, concomitante, desde el punto de vista histórico, con el visigótico. Los visigodos, bastante romanizados, abandonan su propio dialecto germánico y aceptan el romance usado entonces en la Península Ibérica.

Es probable que las personas cultas, como Isidoro de Sevilla, Julián, Ildelfonso, etc. hablaran latín pero los menos cultos harían uso de un latín muy a la romance, bastante parecido al leonés, con las mismas características en que éste se aparta y diferencia del castellano: /j/: ovelle (oveja); /f $-/$ : feito (hecho); /11-/: |llengua (lengua); /-ai-/: carraira (carrera); /au/: lausa (losa). Es normal que tal tipo de romance haya aceptado algunos préstamos del visigodo: rukka $>$ rueca, ganz $>$ ganso, bruto $>$ brotan, muchos nombres de persona, etc.

III. periodo, desde el 711 al 911, corresponde al asturiano-mozárabe.

Está marcado por un acontecimiento histórico capital, la llegada de los árabes al territorio hispánico y el consiguiente retiro de Pelayo, desde Toledo hacia el norte, Asturias, con la resolución de iniciar el proceso de la reconquista e implantar de nuevo el aniquilado reino de Toledo.

El lenguaje toledano se refugia en la capital astur; pero también permanece en Toledo y en otras ciudades, donde queda a merced de la órbita mora bajo el nombre de mozárabe. Tal dialecto posee características fonéticas continuadoras del visigótico, pero también del recién llegado árabe, el cual le da un influjo marcada hasta el Siglo X. En los dialectos romances se da una unidad lingüística peninsular que será rota por el castellano.

IV. periodo. Representa, del 920 al 1067 , la hegemonía del leonés y se caracteriza por una fonética ambigua: carraira, carreira, carrera; sauto, saoto, soto, etc. Continúa la influencia mozárabe y la unidad dialectal de la Península Ibérica.
V. periodo. Del 1067 al 1140 , representa la lucha del castellano por su hegemonía, el cual se desplaza desde su tierra autóctona, la de los castillos, pasa luego por Burgos y una vez burgalizado se dirige hacia Toledo, luego de habarse separado del leonés. Hispania vuelve su mirada hacia Frantia como consecuiencia de la acción cultural de los monjes de Cluny; se deshace del rito mozárabe y en su lugar emplea el rito romano, y la escritura gótica es sustituida por la carolingia. Efecto sobre la naciente lengua son los primeros galicismos, tales como mensaje, homenaje, usaje, vianda, vinagre, etc. Continúa el afianciamiento del dialecto castellano con el fin de implantar la cuña diferencial, romper la unidad lingüística y constituirse en lengua nacional.

Por consiguiente, de este período data la implantación de las características dialectales del castellano.

VI. periodo. Es el concomitante con el literario. La literatura, y más tarde la Academia de la Lengua, se encargarán de darle al castellano una unidad relativa. Una vez formado en lo esencial el español, se vuelve de nuevo a su fuente, el latín por medio de cultismos, semicultismos y neologismos; es lo que se conoce con el superestrato cultural latino.

\section{Contorno lingüístico del castellano}

\section{Algunos vasquismos:}

El castellano, idioma nacido de un latin vulgar cantábrico, vecino de la región éuscara (vasca), desde sus orígenes estuvo asociado con la lengua vasca - lo prueba el romance de las Glosas Emilianenses- cuya influencia en el campo del substrato y del adstrato se manifestó, principalmente, en la fonética, en el léxico y en la morfología:

\section{A) fonética:}

- pronunciación de la /s/ (ápico-alveolar),

- ausencia de pronunciación labiodental de la $/-\mathrm{v}-/$,

- palatalización de la $|-11-|$ y |-nn-|, como stella > estrella, valle $>$ valle; annu $>$ año, pannu $>$ paño, etc., - pronunciación de la /-z-/ de Espaก̃a, 
- la vocal protética seguida de /r/, en ciertos dobletes:

ruga/ arruga, rebata/arrebata, y

- el cambio de $/ \mathrm{f}-\mid>[\mathrm{h}-]$ cuyo rasgo, típico del castellano y del gascón en el conjunto románico, se puede resumir del siguiente modo:
a) foco de origen, la Cantabria,
b) foco de irradiación: norte de Burgos, la Montaña y la Rioja,
c) primeros ejemplos documenta- dos: Castilla y la Rioja,
d) época de la primera documenta- ción: Siglo IX,
e) difusión realizada por el castella- no a través de la reconquista.
f) ejemplos: lat. fabulare $>$ cast. hablar; pero
en port. falar, fr. fabler, it. ant.
favolare; lat. folia $>$ cast. hoja, pero en port. folha, cat. fulla, fr. feuille, it. foglia, rum. foaie; lat. clas. fácere, lat. vul. facere: cast. hacer; pero en port. fazer, fr. faire, lit. fare, rum. a face. De he- cho, el vasco desconocía y desco- noce el sonido /f $-/$ el cual es sustituido por $/ \mathrm{p}-/$ o por $/ \phi \mid$.

\section{B) Léxico:}

- toponimia: Arán (valle), Amaya (límite), etc.,

- antroponimia: Javier, Iñigo (Ignacio), etc.,

- apellidos: Garsea > García, Xemeno $>$ Jimeno, Sancho, Echeverria, etc.,

- nombres comunes: ascua, aquelarre, arroyo, boina, cachorro, chaparrón, de bruces, izquierdo (de ezker), mata, nava, pizarra, zarza y zorra, etc.

\section{C) Morfologia:}

- sufijos en -berri, -én, y sobre todo, la incorporación, como posesivo modal, de los sufijos $-a z,-e z y o z$, tan productivos en la formación de apellidos castellanos, donde sobresalen los terminados en $-e z$, con el significado de "hijo de": Rodríguez, Fernández, Alvarez, Jiménez, Sánchez, etc.
1. Irradiación cántabra:

$$
\begin{aligned}
& - \text { iello }>\text { illo, } \\
& - \text { cl-, }-\mathrm{gl}->-\mathrm{j}-, \\
& -\mathrm{ct}->-\mathrm{ch}-, \\
& \mathrm{j}-, \mathrm{g}->\phi .
\end{aligned}
$$

\section{Irradiación desde Burgos:}

-ariu >ero, y

la fijación de ciertos caracteres vacilantes.

3. Algunas asimilaciones castellanas tomadas de | dialectos circunvecinos.

a) con el este: $/ \mathrm{ai} />[\mathrm{e}], / \mathrm{au} />[\mathrm{o}], / \mathrm{mb} /$ $>$ [m]

b) con el noroeste: palatalizaciones de /pl-/,/cl-/ y /fl-/; y

c) con el centro: $/ \mathrm{e} />$ [ié] y $/ \mathrm{o} />$ [ué].

\section{Conclusión}

Para el origen de Castilla y del Castellano hay que tomar en cuenta los siguientes factores:

1. la romanización, la cual se inició en Hispania, desde el Siglo II antes de Cristo;

2) la implantac ión del latín en tal sitio;

3) la formación del centro urbano-visigodo en Asturias;

4) la creación del desierto separativo entre el norte y el sur, con Castilla como eje conductor;

5) la transferencia de la capital, de de Oviedo a León, por lo largo, difícil y empinados que resultaban los puertos asturianos;

6) el quebrantamiento cultural por obra de los germanos, con cuyas invasiones desaparece la unidad imperial, se pone en peligro la cultura románica y se aísla entre sí lo creado por Roma debido al abandono general, sobre todo de caminos y calzadas romanas y al contacto que pierden las provincias mutuamente,

7) la diferenciación lingüística producida entre las diferentes tribus y pueblos existentes, y

8) al espíritu de rebeldía e independencia de Castilla, que se manifestó en contribuciones políticas, militares, jurídicas, lingüísticas y literarias, que constituyen los aportes nuevos de Castilla, lo cual hizo exclamar al cronista y poeta aúlico del Emperador Alfonso VIII: 
"Castellae vires per saecula fuere rebelles".

Para nombrar sólo un ejemplo, tomemos el campo jurídico: Castilla nombraba sus "Judices" (jefes o caudillos) sin el consentimiento de León, quien era la que hacía antes tales nombramientos en los distintos distritos. Tampoco la Lex Romana fue aceptada por Castilla; puesto que sus habitantes sentían aversión por el "Ordo Toletanus" o ley escrita; más bien sus usos jurídicos eran llevados a la práctica por las "fazañas".

La actitud política en general de Castilla, durante su época gloriosa, como la de Roma en la suya, le trajo muchos beneficios al confuso mundo de entonces. Tal actitud está muy justificada por la defensa, tomada muy a pecho, contra el árabe invasor; y por lo tanto, de lo autóctono, en cuya primera fila marchaba la defensa del patrio suelo y del cristianismo.

\section{Bibliografía}

1. BLAZQUEZ JOSE MARIA, La Romanización, ciclos y temas de la Historia de España, Editorial Istmo, Madrid, 1. m. IO y II', 1974.

2. BOURCIEZ EDOUARD, Eléments de linguistique romane, Ed. Klincksieck, Paris, 1967.

3. DIAZ-PLAJA GUILLERMO, Historia del español, a través de la imagen y el ejemplo, Editorial Ciordia, Buenos Aires, 1968.

4. Dicccionario de Historia de España, Ed. Revista de Occidente, Madrid, 1952.

5. ELCOCK W. D., The romances languages, Ed. Faber and Faber, London, 1960.

6. Enciclopedia de ia cultura española, Editorial Nacional, Madrid, 1963.

7. ENTWISTLE W. J., The spanish language, Ed. Faber and Faber, London, 1969.

8. GARCIA DE DIEGO VICENTE, Gramática histórica española, Ed. Gredos, Madrid, 1970.
El castellano, como las demás lenguas romances, es producto del latín vulgar cantábrico con la presencia de numerosos elementos de sustrato y superestrato con las cuales tuvo y tiene todo tipo de relaciones.

Cabe poner la siguiente cita como aspecto final de este trabajo: "En cuanto un dialecto predomina en el interior de un territorio y la escritura toma importancia en él, en cuanto se desarrollan de forma repetitiva relaciones entre los grupos humanos, algo se está formando por encima de estos dialectos. Los lingüístas hablan de una "fuerza de diálogo recíproco" que se opone a determinadas innovaciones locales, que propaga otras y que favorece, así, la formación de una lengua de comunicación. Entran en juego, aquí, factores muy diveros, políticos, económicos y religiosos, en el sentido de un fenómeno de convergencia. Una lengua unificada de esta manera invade los ámbitos de la administración, de la literatura, etc ".

9. HALL JR. ROBERT A., External history of the romance languages, Ed. Elsevier, Nueva York, 1977.

10. IORDAN IORGU Y MANOLIU MARIA, Manual de lingüistica románica, t. $\mathrm{I}^{\mathrm{O}}, \mathrm{Ed}$. Gredos, Madrid, 1972.

11. KINDER HERMANN Y HILGEMANN WERNER, Atlas histórico mundial (de los origenes a la Revolución Francesa), Ediciones Istmo, Madrid, 1974.

12. LAPESA RAFAEL, Historia de la lengua española, Ed. Gredos, Madrid, 1980.

13. MENENDEZ PIDAL RAMON, Castilla, la tradición, el idioma, Ed. Gredos, Madrid, 1955.

14. MENENDEZ PIDAL RAMON, El idioma español en sus primeros tiempos, Ed. Espasa-Calpe, Madrid, 1973.

15. MENENDEZ PIDAL RAMON, Manual de gramática histórica española, Ed. Espasa-Calpe, Madrid, 1973. 
16. MENENDEZ PIDAL RAMON, Toponimia prerrománica hispánica, Ed. Gredos, Ed. Gredos, Madrid, 1968.

17. METZELTIN MICHAEL, Einführung in die hispanistische Sprachwissen-schaft, Romanistische Arbeitshefte, Ed. Niemeyer Verlag, Tubinga, 1973.

18. MONTEVERDI ANGELO, Manuale d'avviamento agli studi romanzi, Ed. Vallardi, Milán, 1952.

19. PEREGRIN OTERO CARLOS, Evolución $y$ revolución en romance, t. $\mathrm{I}^{\mathrm{O}} \mathrm{y} \mathrm{II}^{\mathrm{O}}$, Ed. Seix Barral, Barcelona, 1976.

20. SAVI-LOPEZ PAOLO, Origenes neolatinos, Ed. Labor S.A., Barcelona, 1935.

21. SECO MANUEL, Gramática esencial del español; introducción al estudio de la lengua, Ed. Aguilar, Madrid, 1977.

22. SPAULDIN ROBERT K., How Spanish grew, Ed. University of California Press, Berkeley and Los Angeles, 1967.
23. TAGLIAVINI CARLO, Origenes de las lenguas neolatinas, Ed. Fondo de Cultura Económica, México, 1973.

24. TOVAR A. Y BLAZQUEZ J. M., Historia de la Hispania Romana, Alianza Editorial, Madrid, 1975.

25. WAANANEN VEIKKO, Introducción al latin vulgar, Ed. Gredos, Madrid, 1975.

26. VIDOS B. E., Manual de lingüistica románica, Ed. Aguilar, Madrid, 1968.

27. VON WARTBURG WALTER, Die Entstehung der romanischen Völker, Max Niemeyer Verlag, Tubinga, 1951.

28. VON WARTBURG WALTER, La fragmentación lingüistica de la Romania, Ed. Gredos, Madri, 1971.

29. WOLFF PHILIPPE, Origen de las lenguas occidentales, 100-1500 d. C., Ed. Guadarrama, Madrid, 1971. 